\title{
Foreign Direct Investment \& Economic Growth in Sub-Saharan Africa: An Empirical Study
}

\author{
Bhavish Jugurnath*, Nitisha Chuckun, Sheereen Fauzel \\ Department of Accounting and Finance, Faculty of Law and Management, University of Mauritius, Réduit, \\ Mauritius \\ Email: "b.jugurnath@uom.ac.mu
}

Received 5 May 2016; accepted 21 August 2016; published 24 August 2016

Copyright (C) 2016 by authors and Scientific Research Publishing Inc.

This work is licensed under the Creative Commons Attribution International License (CC BY).

http://creativecommons.org/licenses/by/4.0/

(c) (i) Open Access

\begin{abstract}
This study has made an attempt to investigate and analyze empirically the impact of Foreign Direct Investment (FDI) on the economic growth for a panel of 32 Sub-Saharan African countries during the period 2008-2014. Both static panel regression techniques and dynamic panel estimates were employed to assess the causal link of our regressors, namely, FDI, trade openness, domestic investment, working population size and the effects of the 2009 European debt crisis on our dependent variable, Gross Domestic Product (GDP) per capita. The evidence from the statistical analysis suggests that aggregated FDI does have a positive and significant impact on economic growth and is thus consistent with the literature, especially with respect to developing countries. Based on static random effects, the inclusion of the 2009 Euro zone crisis did not diverge the results despite its negative impact on economic growth. The contribution of FDI is observed to be relatively higher than domestic investment.
\end{abstract}

\section{Keywords}

Foreign Direct Investment (FDI), Economic Growth, FE \& RE Model, GMM Estimates

\section{Introduction}

Sub-Saharan Africa (SSA) is, geographically, the area of the African continent that lies in the south of the Sahara Desert, with a population exceeding 930 million residents from the 48 countries of the region. These countries are specifically varied, both in size and economic history, with many small countries and some giants such as Nigeria and South Africa. One of the remarkable features of globalization in the 1990s was the flow of private

\footnotetext{
${ }^{*}$ Corresponding author.
}

How to cite this paper: Jugurnath, B., Chuckun, N. and Fauzel, S. (2016) Foreign Direct Investment \& Economic Growth in Sub-Saharan Africa: An Empirical Study. Theoretical Economics Letters, 6, 798-807. 
capital in the form of Foreign Direct Investment (FDI). For Least Developed Countries (LDCs), FDI from Multinational Companies (MNCs) is a crucial path to adopt better technology and more knowledge. The SSA countries participate actively in the global competition for FDI. The growing importance of FDI as a form of external finance to developing countries reflect not only the fact that firms increasingly find benefits in expanding their production internationally but also that host developing countries see potential advantages in FDI over other forms of investments like foreign portfolio investment, in their economies. The aim of this study is to investigate and analyze the impacts of FDI and other drivers on economic growth in Sub-Saharan Africa. This study mainly focuses on analyzing the short run relationships between the causal variables (mainly FDI) and economic growth while considering the impact of the 2009 European Debt crisis and using annual data set ranging from 2008 to 2014. This is done via both a static settings and using dynamics.

Our research differs from previous studies on several levels. First, it assesses the robustness and resilience of the SSA economies to the external financial shocks, such as the 2009 European debt crisis. The impact of external shocks on developing countries is individually measured. Next is how export-oriented strategy and free trade are supposed to be beneficial to Sub-Saharan Africa, given that with globalization, trade openness and FDI are constantly evolving. Not so many researches carried out studies on the effect of FDI in Africa and SSA. Amongst the few, Akinlo [1] considers the effect of FDI in Africa using pooled annual data from twelve countries. His study does cover a range of developing and developed nations, but Nigeria was the only SSA country that included in his sample of 47 countries. Though the exclusion of other Sub-Saharan African countries might have been due to lack of data availability for the variables which the author sought to emphasize, it still highlights the gap in research on FDI in Sub-Saharan African countries which this paper addresses. In our study, a panel data analysis and one-step GMM dynamic regression will be used over the period 2008 to 2014 to assess the impact of FDI in primary, secondary and tertiary sectors as a whole.

The research reveals the importance and impact of FDI, trade openness, domestic investment, working population size and the effects of the Euro Debt crisis of 2009 on economic growth of the SSA economies on aggregate. While most variables have the same effect, the results vary quantitatively, and as for euro debt crisis, it is found to have opposite effects under different methodologies. This article is organized as follows. The second section presents the theoretical framework and brief empirical review of our research and the hypotheses to be tested. Methodological aspects/Research Design are the subjects of the third section, while the fourth section is devoted to the presentation and analysis of results. In the final section, we review the main results and contributions of this study.

\section{Literature Review}

\subsection{Macro-Level FDI Theories}

Lipsey [2] affirmed that the macroeconomic theories try to explain the motivations of the investors to invest in foreign countries. As per, Woldemeskel [3], the macroeconomic determinants affecting the host country's FDI flows are market size, economic growth rate, GDP, infrastructure, natural resources, political situation etc.

\section{1) Capital Market Theory (CMT)}

Being one of the oldest theories of FDI, the CMT stipulates that FDI is determined by interest rates. Boddewyn's [4] CMT focuses on three points that attract FDI to the less developed countries, namely:

- The undervalued exchange rate, which allows lower production costs in the host countries.

- Long term investments in less developing countries will most commonly be FDI instead of purchase of securities.

- Control of host country assets due to limited knowledge about host countries’ securities.

2) Dynamic Macroeconomic Theory

Under this FDI theory, Sanjaya Lall [5] said that the timing of investments depends on the changes in the macroeconomic environment; the latter consists of GDP, domestic investment, real exchange rate, productivity and openness which are the determinants of FDI flows. As per this theory, FDIs are a long term function of multinationals strategies.

3) FDI Theories Based on Exchange Rates

FDI theories based on exchange rate tried to show the relationship between FDI and exchange rate. The theory tries to explain how the flow of FDIs affects the exchange rates. The theory viewed FDIs as a tool of exchange rate reduction. 


\section{4) FDI Theories Based on Economic Geography}

These theories explain why globally successful industries emerge in certain countries. The results found were based on the differences among countries in terms of availability of natural resources, nature of labour force and local demand, infrastructure, etc. These theories also covered the methods by which governments can manipulate the resources within the jurisdiction by various policy actions since economic unit of analysis is defined by political boundaries.

5) FDI Theories Based on Institutional Analysis

Saskia Wilhelms' [6] theory explores the importance of institutional framework on the flows of FDI. It stipulates that political stability is the key factor of a healthy institutional framework. The main determinants of FDI are the institutional variables such as laws, policies and their implementation. The four institutions contributing to FDI flows are governments, markets, education and socio-culture.

\subsection{Micro-Level FDI Theories}

The micro-level FDI theories attempt to explain why MNCs prefer setting up subsidiaries abroad rather than exporting or licensing their products, how MNCs choose their investment locations and why they invest where they do.

1) Hymer's Theory of International Production (1960)

In his theory of International production, Hymer showed that there are two key factors affecting FDI, which are as follows:

- The existence of specific advantages

Due to the exhaustion of investment in home country, firms will be in a favourable position to establish subsidiaries in other countries for resource exploitation. Consequently, they gain more market power, and thus acquire a competitive advantage over their competitors as a result of market imperfections.

- The removal of conflicts in foreign markets

When a firm is trying to enter a foreign market, there is a significant probability conflicts which may arise due to the presence of several firm already established in a foreign market. One way to circumvent this is to collude with the competitors in relation to market sharing. This is an oligopolistic situation, where the firm gains market power and therefore accentuates market imperfections (Grazia [7]). According to Hymer, the MNE was an institution for international production rather than international exchange and proclaimed that FDI involved the transfer of not just finance capital, but a package of resources such as technology, management skill and finance capital.

2) The Product Life Cycle-Vernon (1966)

A product's life span is usually divided in 4 stages introduction, growth, maturity and decline and the place where the product is manufactured shift from one country to another depending on the stage of the product's life cycle. Firms that manufacture innovative products first, achieve monopoly in that production line and when others imitate that product, competition is established gradually.

3) The Eclectic Paradigm-OLI Theory

Dunning [8] proposed a concept on international production called the eclectic paradigm, and he improved it a number of times due to criticisms (Dunning [9]). Indeed, the eclectic paradigm establishes an OLI (Ownership-specific, Location and Internalization advantages) framework to determine and explain the pattern in the movements of FDI and decisions of foreign investors on where they can establish their productive activities. The three main tenets of the OLI theory are explained as follows:

- Ownership-specific advantages

With the advent of globalization and the advancement in technology, corporations are often involved in efficiency-seeking FDI. Firm, which own or have the capacity to own income-generating assets that are geographically dispersed and are not easily possessed by others, are said to have ownership-specific advantages. MNEs with superior comparative advantage relative to other corporations are more capable to achieve growth in the context of foreign production (Dunning [10]).

- Location-specific advantages

Corporations view internalization of the markets as being more and more in their interest for the generation and by maintain control over these assets add value to them. However, governments have to provide attractive investment and fiscal incentive policies, good infrastructures, up-to-date technologies and competent human resources. Successful government interventions and its ability to enforce proper laws are the ways to attract FDI in 
many developing countries.

- Internalization advantages

Firms try to locate value-adding activities in foreign countries. Their profitability will depend on where they manufacture their products in relation to the endowment factors (capital and labour) in those foreign countries in order to have internalization advantages.

The mathematical function is:

$$
\mathrm{FDI}=f(O, L, I)
$$

where:

$$
\begin{aligned}
& O=\text { Ownership, } \\
& L=\text { Location, } \\
& I=\text { Internalization. }
\end{aligned}
$$

\subsection{Empirical Evidences on FDI and Economic Growth}

Throughout decades, FDI's interaction with human capital has received considerable attention. Borensztein, De Gregorio \& Lee [11] found through a cross-country regression and instrumental variables estimation framework for 69 developing countries, in the period 1970-89, that inward FDI has positive effects on growth in parallel with its interaction with human capital. The regressors used to explain economic growth are: initial GDP, government consumption, black market premium on foreign exchange, measures of political instability and political rights, a proxy variable for financial development, inflation rate, measure of the quality of institutions, human capital, FDI, and an interaction term built with FDI and human capital. They concluded that FDI is an important vehicle for the transfer of technology, contributing relatively more to growth than domestic investment. According to them, it should be noted that growth equations are extremely sensitive to proxies of human capital. However, they noted that this positive effect was conditioned by the absorptive capabilities of advanced technologies that need to be accessible by host countries at a certain level.

However, Carkovic and Levine [12] attempt to estimate the effect of FDI on growth by collecting data of two related samples: 72 developed and developing countries. They used cross-sectional data whereby the data for each country was averaged over the full time frame under consideration. The data was further modified by averaging over five-year intervals to exploit time variation. After controlling for variables such as existing economic conditions, the level of human capital and financial development, the authors found that FDI does not exert an independent, positive impact on growth. A different sample specification (developing countries only) and a different dependent variable (the log level of GDP) did not alter the results. Thus, the authors deduced that FDI inflows do not bring a significant positive impact on host countries economic growth.

Alfaro [13] tackles this concern by exploring the relationship between economic growth and sectorial FDI in a panel of 47 developing countries. His findings were segregated; while total FDI has an ambiguous effect on the real per capita GDP growth rate, manufacturing sector FDI has a positive, significant effect on growth. FDI in the primary sector has a significant negative impact on growth, while FDI in the service sector has a negative, but insignificant effect on growth. Wang [14] reaches similar conclusions in a study that focuses on the effect of sectorial FDI in twelve Asian economies. He deduced that aggregated FDI does have a positive effect on growth, but more specifically, the manufacturing FDI has a greater positive effect on growth and primary sector FDI has a negative effect on growth.

\subsection{Summary of Review}

In light of the above studies, the need to explore FDI in SSA has been re-affirmed. For instance, Alfaro's study does cover a range of developing and developed nations, but Nigeria was the only SSA country that included in his sample of 47 countries. Though the exclusion of other Sub-Saharan African countries might have been due to lack of data availability for the variables which the author sought to emphasize, it still highlights the gap in research on FDI in Sub-Saharan African countries which this thesis addresses. On a more important note, this paper attempts to place the discussion on the overall impact of FDI on the economic growth of SSA and to observe the flow of FDI during the European Debt crisis, triggered in 2009. A panel data analysis will be used over the period 2008 to 2014 to assess the impact of FDI in primary, secondary and tertiary sectors as a whole. 


\section{Research Design}

This section provides a description of the data set used in this paper and the procedure used to construct the dependent variable and the regressors, including the descriptive statistics. Our research work has been inspired and empirically supported by various findings and literature review such as Blomstrom et al. [15], Balasubramanyam et al. [16], De Mello [17], and Alfaro [13]. The alternative hypotheses fashioned are as follows and their null hypotheses $\left(\mathrm{H}_{0}\right)$ being their contrary:

$\mathrm{H}_{1}$ : FDI does not impact on economic growth,

$\mathrm{H}_{2}$ : Trade openness does not impact on economic growth,

$\mathrm{H}_{3}$ : Domestic investment does not impact on economic growth,

$\mathrm{H}_{4}$ : Population size does not impact on economic growth,

$\mathrm{H}_{5}$ : Euro zone crisis does not impact on economic growth.

\subsection{Dependent Variable}

Following Fauzel et al. [18], the dependent variable in this model is GDP per Capita. Levels of GDP per capita are obtained by dividing GDP at current market prices by midyear population. GDP is the sum of gross value added by all resident producers in the economy plus any product taxes minus any subsidies not included in the value of the products. Data are in current US dollars.

\subsection{Independent Variables}

FDI. Foreign Direct Investments are the net inflows of investment to acquire a lasting management interest (10 percent or more of voting stock) in an enterprise operating in an economy other than that of the investor. It is the sum of equity capital, reinvestment of earnings, other long-term capital, and short-term capital as shown in the balance of payments. Inward FDI reflects the net inflows, derived from new positive investment flows less disinvestment, and this net amount is divided by GDP (see Fauzel [19]).

OPNS. Trade Openness or trade to GDP ratio is used as a proxy to account for the effect of international trade i.e. openness on economic growth. It is computed by adding exports and imports of goods and services measured as a share of GDP. Productivity improvement in the country is expected due to the exit of less efficient firms after trade liberalisation or simply a decline in transport costs (Melitz [20]).

GCF. Gross Capital Formation is a measure of gross domestic investment. It consists of outlays on additions to the fixed assets of the economy plus net changes in the level of inventories. Theoretically, GCF affects economic growth by either increasing the level of physical capital stock in domestic economy directly (Plossner [21]), or promoting technology indirectly (Levine and Renelt [22]).

POP. The working population of each country is used as a proxy for labour force.

$\mathbf{D}_{1}$. This dummy variable records the effects of the Euro debt crisis 2009 on the developing SSA economies.

\subsection{Regression Model}

Based on previous empirical literature and data availability, the linear econometric model that will be used in this study is as follows:

$$
\mathrm{GDPPC}_{i t}=\alpha_{i}+\beta_{1} \mathrm{FDI}_{i t}+\beta_{2} \mathrm{OPNS}_{i t}+\beta_{3} \mathrm{GCF}_{i t}+\beta_{4} \mathrm{POP}_{i t}+\beta_{5} \mathrm{D}_{1 i t}+\varepsilon_{i t}
$$

where:

$\mathrm{GDPPC}_{i t}=$ GDP per Capita Growth (\%) at time $t$,

$\mathrm{FDI}_{i t}=$ Inward FDI (net inflows) as a $\%$ of GDP at time $t$,

$\mathrm{OPNS}_{i t}=$ Trade openness as a $\%$ of GDP, i.e. (Imports + Exports) as a \% of GDP at time $t$,

$\mathrm{GCF}_{i t}=$ Gross Capital Formation (\%) at time $t$,

$\mathrm{POP}_{i t}=$ Population Size at time $t$,

$\mathrm{D}_{1 i t}=1$ for 2009-2011,

0 for 2012-2014.

The subscripts $i$ and $t$ represent countries and time periods respectively.

Logarithmically transforming variables in a regression model is a very common way to handle situations where a non-linear relationship exists between the independent and dependent variables. Using the logarithm of 
one or more variables instead of the un-logged form makes the effective relationship non-linear, while still preserving the linear model and increases its robustness. Thus, a linear - log model is used as follows:

$$
\ln \mathrm{GDPPC}_{i t}=\alpha_{i}+\beta_{1} \mathrm{FDI}_{i t}+\beta_{2} \mathrm{OPNS}_{i t}+\beta_{3} \mathrm{GCF}_{i t}+\beta_{4} \operatorname{lnPOP}_{i t}+\beta_{5} \mathrm{D}_{1 i t}+\varepsilon_{i t} .
$$

Equation (2) is the principal equation that is used to conduct regressions and other calculations for the purpose of data analysis.

\subsection{Analysis of Results}

Based on all the tests conducted, we can observe that under the static fixed effect regression, FDI inflows and economic growth share a positive relationship which is not significant. As for the effects of the Euro zone crisis, it has a negative impact on economic growth but like FDI, it turned out to be insignificant. Domestic investment and working population size have a significant and positive impact on growth while trade openness has a negative significant link with GDP per capita. Under the static random effect model and dynamic panel GMM estimation (one-step), the independent variables: FDI, domestic investment and working population size have a significant and positive relationship with economic growth while trade openness has a negative significant impact on growth. However, under the random effect model, the Euro zone crisis effects are reported to be significant and negative while under the GMM estimation, the crisis variable has a positive significant impact on GDP per capita. The extent of FDI reported under both models differs greatly whereby the random effect model reports a 0.0412 percent change while under the GGM estimation it is 0.58 percent.

Under the Random Effects model (see Table 1), the coefficient of determination $\left(\mathrm{R}^{2}\right)$ explains 55.74 percent the variability of the response data around its mean, i.e., the predictors under this model adequately fit our data. This model better caters for the overall effect of predictor variables such as the impact of Euro zone crisis on the various growths of the SSA economies. This model portrays the similar behaviour as pooled OLS with parameter estimates of 0.0412 for FDI demonstrating a positive and significant relationship at 1 percent. This implies that for every percentage increase in FDI inwards, ceteris paribus, GDP per capita will increase by 0.0412 percent. This positive contribution is in line with the theoretical underpinnings discussed earlier. FDI increases technical progress in the host country by means of a contagion effect (Findlay, 1978) which eases the adoption of advanced managerial procedures by the local firms. The impact of FDI in SSA is also reported to be relatively lower as compared to other studies, for instance De Gregorio [11] for Latin American countries, Wang [14] for the Asian economies case and Campos and Kinoshita [23] for transitional economies. This can be de facto explained that African countries have been among the lowest beneficiaries of FDI.

As for domestic investment, it has a statistically significant and positive contribution on growth though to a lesser extent than FDI. This coincides with the work of Borensztein et al. [11]. From a different viewpoint, climate change provides African governments with an added incentive to establish policies that are extensively overdue and to demonstrate leadership on the global platform.

From this study, working population size indeed affects economic growth to a very large extent with a coefficient estimate of 0.25 . Throughout history, human populations have experienced deficiencies in food production. Evolutions in the use of renewable energy and technical progress, the protection of climate, ecosystems, biological diversity and agricultural intensification are important drivers in enhancing standard of living of the SSA populations and to achieve fruition in economic growth. Thus, insights into the future development of the agricultural sector are of great concern to society and policymakers.

Trade Openness has a negative and statistically significant relationship with at 1 percent with GDP per capita. From the RE regression, it is reported to have a coefficient estimate of -0.00364 percent which indicates a slight negative impact on economic growth.

Finally, the impact of Euro zone crisis on economic growth is found to be negative and statistically significant at 1 percent. The effects of the Euro zone crisis which lasted from 2009 to 2012 has a negative coefficient estimate of -0.148 percent and these have drastically affected the SSA economies. The growing dependence of SSA on export receipts from tourism and transportation services, which also tend to be pro-cyclical, heightens the region's exposure to the crisis. The food and fuel price shocks of 2007-08 that preceded the current global Euro zone crisis weakened the external position of net importers of food and fuel, caused inflation to accelerate, and impeded growth prospects. 
Table 1. Regression results and static panel data estimates.

\begin{tabular}{|c|c|c|c|}
\hline Variable & Pooled OLS Robust Estimates & Fixed Effect Robust Estimates & Random Effect Estimates \\
\hline \multirow[b]{2}{*}{ Constant } & 9.288017 & -11.97807 & 11.49086 \\
\hline & $(8.78)^{* * *}$ & $(-2.54)^{* *}$ & $(6.74)^{* * *}$ \\
\hline \multirow[b]{2}{*}{ FDI } & 0.0421434 & 0.001944 & 0.041200 \\
\hline & $(4.13)^{* * * *}$ & $(1.35)$ & $(2.86)^{* * *}$ \\
\hline \multirow{2}{*}{ OPNS } & 0.0106538 & -0.0048339 & -0.0036478 \\
\hline & $(4.13)^{* * *}$ & $(-2.73)^{* * *}$ & $(-3.70)^{* * *}$ \\
\hline \multirow{2}{*}{ GCF } & 0.028305 & 0.007671 & 0.0079159 \\
\hline & $(4.54)^{* * *}$ & $(2.79)^{* * *}$ & $(3.83)^{* * *}$ \\
\hline \multirow{2}{*}{ POP } & -0.2118684 & 1.2358 & 0.2528303 \\
\hline & $(-3.57)^{* * *}$ & $(4.13)^{* * *}$ & $(2.37)^{* *}$ \\
\hline \multirow{2}{*}{$\mathrm{D}_{1}$} & -0.1093489 & -0.0207388 & -0.1483518 \\
\hline & $(-0.92)$ & $(-0.70)$ & $(-7.16)^{* * *}$ \\
\hline $\mathrm{R}^{2}$ & 0.4387 & 0.4387 & 0.5574 \\
\hline F-test & 32.23 & 34.80 & 32.23 \\
\hline $\begin{array}{l}\text { Diagnosis Tests: } \\
\text { White's General Test } \\
\text { (Pooled OLS) }\end{array}$ & Prob $>$ Chi $=0.0002$ & & \\
\hline Hausman Test & & Prob $>$ Chi $2=0.0000$ & \\
\hline
\end{tabular}

Note: Coefficients estimates and t values in parentheses are indicated above. The quantities in brackets are the heteroskedastic robust $\mathrm{t} / \mathrm{z}$-values. ${ }^{* * *}{ }^{* *}$, ${ }^{*}$ indicate level of significance at $1 \%, 5 \%$ and $10 \%$ respectively. No serial correlation was detected according to Bhargava, Franzini and Narendranathan (BFN) [25]. Heteroskedasticity is present.

As for the results from the dynamic panel analysis (one-step GMM estimation) (see Table 2), they validate the hypothesis that FDI is conducive to growth on our selected countries even in the short run. Our findings on FDI coincide with results of Seetanah et al. [24]. In fact the value of the coefficient of FDI is about 0.58 percent which has a strongly positive impact and statistically significant relationship of 1 percent with economic growth of Sub-Saharan countries. As explained under the static regression setting, trade openness is found to be statistically significant at 1 percent and has negative impacts on GDP per capita. Under the dynamic regression model, it is observed that the effects of financial crisis on our dependent variable (GDP per capita) has a positive coefficient estimate of 0.072 percent and is statistically significant at 5 percent. The Sargan test is performed in order to ensure that the whole specification does not have any correlation issue amongst the residuals and the instruments used. Our regression model shows that Prob > Chi 2 is greater than 5 percent. This implies that the over-identifying restrictions are valid for our regression. The Arellano-Bond serial correlation test seeks to verify whether the instruments used are valid and the error term does not display any serial correlation. The aim is to accept the $\mathrm{H}_{0}$ which is no autocorrelation at 5 percent significance level. There is no significant evidence against the null hypothesis of zero autocorrelation in the first-differenced errors at order 1, i.e., there is no serial correlation in the first-differenced errors at both order 1 and 2 . This implies that the model specification is valid 
Table 2. Dynamic panel data estimation (first step GMM estimator).

\begin{tabular}{|c|c|}
\hline Variable & GMM Estimates \\
\hline Constant & $\begin{array}{l}-24.326 \\
(-5.57)^{* * *}\end{array}$ \\
\hline GDPPC (L1) & $\begin{array}{l}0.3580 \\
(2.40)^{* *}\end{array}$ \\
\hline FDI & $\begin{array}{c}0.5826 \\
(4.74)^{* * *}\end{array}$ \\
\hline OPNS & $\begin{array}{l}-0.00342 \\
(-3.41)^{* * *}\end{array}$ \\
\hline GCF & $\begin{array}{c}0.003824 \\
(1.71)^{*}\end{array}$ \\
\hline POP & $\begin{array}{c}1.8465 \\
(6.66)^{* * *}\end{array}$ \\
\hline $\mathrm{D}_{1}$ & $\begin{array}{l}0.07221 \\
(2.26)^{* *}\end{array}$ \\
\hline $\begin{array}{c}\text { Diagnosis Tests } \\
\text { Sargan Test of Over identifying Restrictions }\end{array}$ & Prob $>$ Chi $2=0.1304$ \\
\hline Arellano-Bond Test of $1^{\text {st }}$ Order Autocorrelation & Prob $>$ Chi $2=0.0546$ \\
\hline Arellano-Bond Test of $2^{\text {nd }}$ Order Autocorrelation & Prob $>$ Chi $2=0.3178$ \\
\hline
\end{tabular}

Note: The z-values are in parentheses. ${ }^{* * *},{ }^{* *},{ }^{*}$ indicate level of significance at $1 \%, 5 \%$ and $10 \%$ respectively. AR (2) is the test for second order serial correlation. Sargan statistics is to test for over-identifying restrictions is valid.

and the error term is free from any autocorrelation issue.

\section{Conclusion}

This study examines the relationship of FDI and economic growth for selected Sub-Saharan economies during the period 2008 to 2014. The selection was based on data availability, including the most important economies and all the major sectors in Sub-Saharan Africa. The evidence from the statistical analysis suggests that aggregated FDI does have a positive and significant relationship on economic growth and is thus consistent with the literature, especially with respect to developing countries. Based on static random effects, the inclusion of the 2009 Euro zone crisis did not diverge the results despite its negative impact on economic growth. The contribution of FDI is observed to be relatively higher than domestic investment. It is most likely that a foreign firm that decides to enter the local market through FDI enjoys lower costs and higher productive efficiency than its domestic competitors. Working population size is seen to contribute significantly and positively to economic growth. Education is viewed as the primary empowering tool to deduce that countries with more educated workforces are better positioned to exploit advanced technologies that might be gained as a result of FDI. The positive link is also confirmed when applying GMM first-estimator. Thus FDI does not only precede growth and output level of the countries but also follow growth.

\section{Recommendations}

FDI demonstrates a significant positive rise on economic growth. FDI from MNCs has played a significant role in the economic development of the SSA economies by creating job opportunities, transferring technology and know-how and at the same time motivating the local private sector to improve their performance in the competition. More diversification is necessary so that the level FDI inflows increases and becomes more sustainable in 
the future. Statistical evidences from both static and dynamic tests show that trade openness has a negative significant impact on economic growth. Policymakers can set up and improve political strategies and corporate tax policies by reviewing tax structures, and investing in local productions, both on small and large scales. Export diversification policies can be positively associated with economic growth. The political dominance of multinational companies is still far too strong. Governments of the major emitting countries should place a stringent price policy on emissions of greenhouse gases by taxing them, instead of effectively subsidising them. Policymakers should promote green technology which is now the trendy tool to unlock Sub-Saharan Africa's economic and energy potential. This will not only help to eradicate poverty, build more productive labour force and meet the economic needs of the SSA's poorest countries and people, but it will also help in contributing to international cooperation and enhance growth and economic development. Hence, the above results highlight the economic importance of FDI and provide new evidences for the case of African economies.

\section{References}

[1] Akinlo, A.E. (2004) Foreign Direct Investment and Growth in Nigeria: An Empirical Investigation. Journal of Policy Modeling, 26, 627-639. http://dx.doi.org/10.1016/j.jpolmod.2004.04.011

[2] Lipsey, R.E. (2001) Foreign Direct Investment and the Operations of Multinational Firms: Concepts, History, and Data. National Bureau of Economic Research, No. w8665. http://dx.doi.org/10.3386/w8665

[3] Woldemeskel, S.M. (2008) Determinants of Foreign Direct Investment in Ethiopia. http://arno.unimaas.nl/show.cgi?fid=15195

[4] Boddewyn, J.J. (1985) Theories of Foreign Direct Investment and Divestment: A Classificatory Note. Management International Review, 57-65.

[5] Lall, S. (1997) Selective Policies for Export Promotion: Lessons from the Asian Tigers. Vol. 43, UNU World Institute for Development Economics Research.

[6] Wilhelms, S.K. and Witter, M.S.D. (1998) Foreign Direct Investment and Its Determinants in Emerging Economies. United States Agency for International Development, Bureau for Africa, Office of Sustainable Development.

[7] Ietto-Gillies, G. (2007) Theories of International Production: A Critical Perspective. Critical Perspectives on International Business, 3, 196-210. http://dx.doi.org/10.1108/17422040710774987

[8] Dunning, J.H. (1977) Trade, Location of Economic Activity and the MNE: A Search for an Eclectic Approach. Macmillan, London.

[9] Dunning, J.H. (1988) The Eclectic Paradigm of International Production: A Restatement and Some Possible. Journal of International Business Studies, 19, 1-31. http://dx.doi.org/10.1057/palgrave.jibs.8490372

[10] Dunning, J.H. (2001) The Eclectic (OLI) Paradigm of International: Past, Present and Future. International Journal of the Economics of Business, 8, 173-190. http://dx.doi.org/10.1080/13571510110051441

[11] Borensztein, J., De Gregorio, J. and Lee, J.-W. (1998) How Does Foreign Direct Investment Affect Economic Growth? Journal of International Economics, 45, 115-135. http://dx.doi.org/10.1016/S0022-1996(97)00033-0

[12] Carkovic, M.V. and Levine, R. (2002) Does Foreign Direct Investment Accelerate Economic Growth? U of Minnesota Department of Finance Working Paper.

[13] Alfaro, L., Areendam, C., Sebnem, K.-O. and Selin, S. (2003) FDI and Economic Growth: The Role of Local Financial Markets. Journal of International Economics, 61, No. 1.

[14] Wang, M. (2002) Manufacturing FDI and Economic Growth: Evidence from Asian Economies. Department of Economics, University of Oregon Mimeo.

[15] Blomstrom, M., Lipsey, R.E. and Zejan, M. (1993) Is Fixed Investment the Key to Economic Growth? National Bureau of Economic Research, No. w4436. http://dx.doi.org/10.3386/w4436

[16] Balasubramanyan, V.N., Salisu, M. and Sapsford, D. (1996) Foreign Direct Investment and growth in EP and IS Countries. The Economic Journal, 106, 92-105.

[17] De Mello, L.R. (1999) Foreign Direct Investment-led Growth: Evidence from Time Series and Panel Data. Oxford Economic Papers, 51, 133-151. http://dx.doi.org/10.1093/oep/51.1.133

[18] Fauzel, S., Seetanah, B. and Sannassee, R.V. (2014) A PVAR Approach to the Modeling of FDI and Spill Overs Affects in Africa. International Journal of Business and Economics, 13, 181.

[19] Fauzel, S., Seetanah, B. and Sannassee, R.V. (2015) Foreign Direct Investment and Welfare Nexus in Sub Saharan Africa. The Journal of Developing Areas, 49, 271-283.

[20] Melitz, M.J. (2003) The Impact of Trade on Intra-Industry Reallocations and Aggregate Industry Productivity. Econo- 
metrica, 71, 1695-1725. http://dx.doi.org/10.1111/1468-0262.00467

[21] Plossner, C. (1992) The Search for Growth in Policies for Long-Run Economic Growth. Federal Reserve Bank of Kansas City, Kansas City, MO.

[22] Levine, R. and Renelt, D. (1992) A Sensitivity Analysis of Cross-Country Growth Regressions. The American Economic Review, 942-963.

[23] Campos, N.F. and Kinoshita, Y. (2002) Foreign Direct Investment as Technology Transferred: Some Panel Evidence from the Transition Economies. The Manchester School, 70, 398-419. http://dx.doi.org/10.1111/1467-9957.00309

[24] Seetanah, B. and Rojid, S. (2011) The Determinants of FDI in Mauritius: A Dynamic Time Series Investigation. African Journal of Economic and Management Studies, 2, 24-41. http://dx.doi.org/10.1108/20400701111110759

[25] Bhargava, A., Franzini, L. and Narendranathan, W. (1982) Serial Correlation and the Fixed Effects Model. The Review of Economic Studies, 49, 533-549. http://dx.doi.org/10.2307/2297285

\section{Submit or recommend next manuscript to SCIRP and we will provide best service for you:}

Accepting pre-submission inquiries through Email, Facebook, LinkedIn, Twitter, etc.

A wide selection of journals (inclusive of 9 subjects, more than 200 journals)

Providing 24-hour high-quality service

User-friendly online submission system

Fair and swift peer-review system

Efficient typesetting and proofreading procedure

Display of the result of downloads and visits, as well as the number of cited articles

Maximum dissemination of your research work

Submit your manuscript at: http://papersubmission.scirp.org/ 